\title{
Seasonal variations in the intermediate metabolism of the crayfish Parastacus brasiliensis (Crustacea, Decapoda, Parastacidae) in the natural environment and experimental culture
}

\author{
Bibiana K. Dutra, Caroline Zank, Karina M. da Silva, Maria R. Conter \\ \& Guendalina T. Oliveira
}

1. Departamento de Ciências Morfofisiológicas, Laboratório de Fisiologia da Conservação, Faculdade de Biociências, Pontifícia Universidade
Católica do Rio Grande do Sul, Avenida Ipiranga, 6681 Prédio 12C Sala 270, 90619-900 Porto Alegre, RS, Brazil. (guendato@pucrs.br)

\begin{abstract}
The goal of this study was to evaluate the effects of seasonal variations on energy metabolism in different tissues of the freshwater crayfish Parastacus brasiliensis (von Martens, 1869). Crayfish were collected monthly from January 2001 to January 2003 in São Francisco de Paula, Rio Grande do Sul, Brazil, in a stream and in a culture tank. Haemolymph samples were collected from each crayfish in the field with a syringe, by puncturing the membrane at the base of the chelipeds. Hepatopancreas, gills, and abdominal muscle were removed for determination of free glucose, glycogen, total lipids, and triglycerides. The haemolymph samples were used for determination of glucose, total proteins, total lipids, and triglycerides. Statistical analysis revealed significant differences in biochemical composition in crayfish collected in the stream compared to the experimental tank during the year, principally in glucose and triglycerides in haemolymph, glycogen and total lipids in all tissues study, and triglycerides only in abdominal muscle. The regular food intake partially modified these seasonal variations of the metabolic pattern. Environmental conditions (e.g., food availability and water temperature) and reproductive period appeared to be the main factors influencing the seasonal patterns of variation in energy metabolism.
\end{abstract}

KEYWORDS. Crayfish, lipids, triglycerides, glucose, proteins.

RESUMO. Variações sazonais do metabolismo intermediário do lagostim Parastacus brasiliensis (Crustacea, Decapoda, Parastacidae) no seu ambiente natural e em cultura experimental. O objetivo deste estudo foi avaliar o efeito das variações sazonais no metabolismo energético em diferentes tecidos do lagostim de água-doce Parastacus brasiliensis (von Martens, 1869). Os lagostins foram coletados mensalmente de Janeiro de 2001 a Janeiro de 2003 em São Francisco de Paula, Rio Grande do Sul, Brasil, no riacho e no tanque de cultivo. Amostras de hemolinfa foram coletadas de cada lagostim em campo com seringa, por punção na membrana da base dos quelípodos. Hepatopâncreas, brânquias e músculo abdominal foram removidos para a determinação dos níveis de glicose livre, de glicogênio, de lipídios totais e de triglicerídeos. As amostras de hemolinfa foram utilizadas para a determinação dos níveis de glicose, de proteínas totais, de lipídios totais e de triglicerídeos. As análises estatísticas revelaram uma variação significativa na composição bioquímica dos lagostins coletados no riacho quando comparados com os do cultivo experimental durante o ano, principalmente da glicose e dos triglicerídeos na hemolinfa, glicogênio e lipídios totais em todos os tecidos estudados, e dos triglicerídeos somente no músculo abdominal. O aporte regular de alimento modificou parcialmente estas variações sazonais do padrão metabólico. As condições ambientais (ex.; disponibilidade de alimento e a temperatura da água) e o período reprodutivo parecem ser os principais fatores a influenciar os padrões sazonais da variação do metabolismo energético.

PALAVRAS-CHAVES. Lagostim, lipídios, triglicerídeos, glicose, proteínas.

In their habitats, crustaceans are exposed to a large number of environmental variables, which follow annual and daily cycles according to the geographical region and which affect their behavior, feeding and metabolism. Study of the intermediate metabolism in crustaceans has revealed the existence of wide inter- and intra-specific variability, which makes it difficult to determine a standard metabolic profile (OliveIra et al., 2003). This variability can occur because of multiple factors, such as habitat, stage in the molt cycle, sexual maturity (especially in females), feeding state, food availability and seasonality, due to the fact that these factors determine different patterns of metabolic response (Schirf et al., 1987; KuCHARSKI \& DA SILVA, 1991b).

Glucose is the principal monosaccharide present in the haemolymph of crustaceans, and it serves six main purposes: synthesis of mucopolysaccharides, synthesis of chitin, synthesis of ribose and nicotinamide adenine dinucleotide phosphate reduced (NADPH), formation of pyruvate and synthesis of glycogen (CHANG \& O'CONNOR,
1983; HERREID \& FuLL, 1988). Stable glucose haemolymph levels are very important for the regular functioning of the nervous, muscle and reproductive systems. Glucose can be accumulated in the form of glycogen in the hepatopancreas and in other tissues, such as the muscles and the gills (VInAGRe \& Da Silva, 1992, 2002; Oliveira et al., 2003).

The storage location of glycogen varies according to the species (JOHNSTON \& DAVIES, 1972; HERREID \& FULL, 1988). The absence of a central glycogen deposit seems to be an adaptation of several classes of animals to changes in environmental factors (Носнаснка et al., 1970). The stored glycogen is utilized in adaptation to molting, hypoxia and/or anoxia, osmoregulation, growth, reproduction and during fasting periods (CHANG \& O'Connor, 1983; Kucharski \& Silva, 1991a, 1991b; Oliveira et al., 2001, 2004).

In the absence of an adipose tissue in crustaceans, the hepatopancreas seems to be the main site of lipid storage (O'CONNOR \& Gilbert, 1968; ChANG \& O'CONNOR, 1983; Herreid \& Full, 1988; Kucharski \& Da Silva, 
1991a; MuRIANA et al., 1993; GARCíA et al., 2002), although lipids can also be accumulated in muscle tissue and in the female gonad (Komatsu \& Ando, 1992). In the estuarine crab Chasmagnathus granulatus Dana, 1851, for example, Kucharski \& DA SiLVA, (1991b) found that total lipids represent more than $20 \%$ of the hepatopancreas' weight.

Several studies have demonstrated that during periods of high energy demand, such as molting and gametogenesis, there is a pronounced degradation of lipids, especially those stored in the hepatopancreas. In C. granulatus, the levels of lipids in muscle tissue varied seasonally, and were highest in summer; whereas lipid levels in the hepatopancreas decreased during the reproductive period, in spring and summer (KUCHARSKI \& DA SiLVA, 1991a). Rosa \& Nunes (2003b) observed a significant increase in the levels of total lipids and cholesterol in gonadal tissue of Aristeus antennatus Risso, 1816, Parapenaeus longirostris Lucas, 1846, and Nephrops norvegicus Linnaeus, 1758 from the Portugal coast. This increase may be related to the stage of ovary maturation.

The muscle is apparently the main protein-storage location in crustaceans. In decapods, the free amino acids in the tissues reach levels ten times higher than those observed in vertebrates. Several studies suggest that these amino acids participate in osmoregulation and in cell volume control (GILles, 1982; ChANG \& O'CONNOR, 1983; SCHEIN et al., 2004). Other studies have demonstrated variation in protein content during ovarian development in crustaceans as well. These variations may result from increased biosynthesis of several proteins, including enzymes, hormones, and lipoproteins involved in gonadal maturation (YeHeZKel et al., 2000; Rosa \& NuNEs, 2003a, 2003b).

Cultivated crayfish are of great economic value in some countries, mainly in Europe, Chile, the southern United States and Australia. In Brazil, freshwater crayfish are not usually consumed, perhaps because of the regional distribution of the species and also the difficulty in harvesting the natural populations.

The family Parastacidae is represented in South America by the genera Parastacus Hulex, 1879, Samastacus Riek, 1971, and Virilastacus Hobbs, 1991. Only members of Parastacus (von Martens, 1869) occur in Brazil, preferentially in marshy lentic environments on the plains, and in small, slowly flowing streams (BucKuP \& Rossi, 1980; FRIES, 1980; FonTOURA \& BUCKUP, 1989a). The majority of the species construct underground habitations in the form of simple or branched tunnels that reach groundwater level and have one or more openings on the surface. The animals are nocturnal, when they leave their burrows to hunt for food in or near the water (BuCKuP, 1999). Recently, in the region of São Francisco de Paula, at an altitude of 900 meters above sea levels, a new population of $P$. brasiliensis was found in the Pró-Mata Center for Research and Nature Conservation. This is the first record in Brazil of a freshwater crayfish living at high altitude and low temperatures. Its accelerated growth and rapid maturation, together with its ease of handling, make this species, P. brasiliensis Von Martens, 1869, a good candidate for experimental culture programs.
In comparison with the extensive literature dealing with the biochemistry and metabolism of marine and estuarine crustaceans, fewer studies have considered freshwater crustaceans. The present study propose to evaluate the effects of seasonal variations on energy metabolism in different tissues of the freshwater crayfish P. brasiliensis, in an experimental culture tank and in the natural environment of Garapiá Creek, in the Pró-Mata area, São Francisco de Paula. The purpose was to obtain basic physiological data to support adequate management of these populations.

\section{MATERIAL AND METHODS}

The animals were used with the permission of the Ethic Committee of the Pontifícia Universidade Católica do Rio Grande do Sul (License 0002/03).

The study was carried out in the Pró-Mata Center for Research and Nature Conservation, which consists of an area about 4500 ha and between 600 and 900 meters a.s.l., located in the municipality of São Francisco de Paula, Rio Grande do Sul, between $29^{\circ} 27^{\prime}$ and $29^{\circ} 35^{\prime} \mathrm{S}$ and $50^{\circ} 08^{\prime}$ and $50^{\circ} 15^{\prime} \mathrm{W}$.

Experimental procedures. Near Garapiá Creek in the Pró-Mata reserve, a masonry tank 4.1 meters long by 2.5 meters wide was constructed. The tank was placed on sloping ground so that its foot was 1 meter lower than the water source at its head, in order to provide for a continuous supply of flowing water even during the dry season. To provide the most natural environment possible, two rows of 6-hole bricks on each side furnished artificial burrows for the animals, and two rows of grass taken from the creek were also added. Twenty ovigerous females with carapace lengths between $2.8 \mathrm{~cm}$ and $4.7 \mathrm{~cm}$ were placed in the tank, and then were removed after their young hatched. The young crayfish were collected when they reached the adult stage. Adult $P$. brasiliensis with carapaces 2.8 to $4.7 \mathrm{~cm}$ long were collected in each season, between 2001 and 2003, from Garapiá Creek, and also from the experimental culture tank. In addition to the natural diet available in the tank, the cultured crayfish were fed twice a week with a protein-rich, pelletized ration (Water content $12.0 \%$, Protein $21.0 \%$, Ether extract $8.0 \%$, Fiber $4.0 \%$, Minerals $10.0 \%$, Calcium $2.5 \%$ and Phosphorus $1.0 \%$ ).

In each season, six or seven crayfish in intermolt stage were collected from the creek and from the tank. They were not separated by sex. In parastacids, the male genital pore is located on the coxopodite of pereiopod 5, and the female pore on the coxopodite of pereiopod 3 . The presence of both pairs of genital pores may indicate hermaphroditism, and makes it difficult to determine the sex in this species. Also, the previous calcification of the genital opening (pore) can be present in immature females (Almeida \& BuckuP, 1999; SiLVA-CAStiglioni et al., 2007).

Samples of haemolymph were collected with a syringe containing $10 \%$ potassium oxalate as an anticlotting agent, and were frozen for later determination of glucose, total proteins, total lipids, and triglycerides. The animals were then frozen for later extraction of the main metabolite storage tissues (hepatopancreas, gills, and abdominal muscle). 
Biochemicam measurements. The metabolic parameters of the haemolymph sample of each animal were determined in triplicate using spectrophometric methods a measured as follow: a. Glucose levels by the glucose-oxidase method, using a Bioclin Kit (glucose GOD-CLIN). Results are expressed in mg/dl; b. Total lipids by the sulfophosphovanillin method (FrIngs \& DunN, 1970), with the results expressed in $\mathrm{mg} / \mathrm{ml}$; c. Triglycerides using a Biodiagnostic Kit (GPO Trinder), and are expressed in $\mathrm{mg} / \mathrm{ml}$; c. Proteins following the method described by LowRy et al. (1957), using bovine albumin (Sigma Chemical $\mathrm{Co} / \mathrm{St}$. Louis, MO) as the reference substance. Results are expressed in $\mathrm{mg} / \mathrm{dl}$.

The metabolic parameters of the tissue sample from each animal were determined in triplicate using spectrophometric methods and extracted as follow: a. Lipids were extracted from tissue homogenized with an Omni Mixer Homogenizer in a 2:1 (v/v) chloroformmethanol solution, according to FoLCH et al. (1957). Total lipids in this homogenate were determined by the sulfophosphovanillin method (Frings \& DunN, 1970). Triglycerides were measured by the reactions of lipase, glycerokinase, 1-P-glycerol oxidase, and peroxidase enzymes (Biodiagnostic Kit / GPO Trinder). Results are expressed as $\mathrm{mg} / \mathrm{g}$ of tissue. b. Glycogen was extracted from tissues following the method described by VAN HANDEL (1965), and glycogen levels in the animals were determined as glucose equivalent (glucose-oxidase method), after acidic hydrolysis $(\mathrm{HCl})$ and neutralization $\left(\mathrm{Na}_{2} \mathrm{CO}_{3}\right)$, following the method of GEARY et al. (1981). Glucose was quantified using a Biodiagnostic kit (glucoseoxidase). Results are presented as $\mathrm{mg} / \mathrm{g}$ of tissue. c. Free glucose was determined according to CARR \& NEFF (1984). The tissue samples were weighed and homogenized with Ultra-Turrax in a $100 \mathrm{mM}$ sodium citrate solution, boiled for 10 minutes, agitated, cooled to ambient temperature, and stored at $20^{\circ} \mathrm{C}$ for at least one week. To separate the lipid fraction, the samples were mixed in a $2: 1(\mathrm{v} / \mathrm{v})$ chloroform-methanol solution in the ratio of $2: 1(\mathrm{w} / \mathrm{v})$ and centrifuged for 10 minutes at $2500 \mathrm{rpm}$. The free glucose concentration was determined by the glucoseoxidase colorimetric method (Labtest Kit) in the intermediate fraction obtained after centrifugation. The results are expressed as $\mathrm{mg} / \mathrm{g}$ of tissue.

Statistical analyses. For statistical analysis of the seasonal variations, a one-way ANOVA test was used, followed by a Bonferroni test. For comparison between environments (stream and culture tank), a two-way ANOVA was used. The significance level adopted was 5\%. All the tests were done with the program Statistical Package for the Social Sciences (SPSS- 11.5) for Windows. All the metabolic parameters were homogeneous (Levene test), and were normally distributed (KolmogorovSmirnov test).

\section{RESULTS}

The water temperature varied similarly in both systems during the year, being warmest in summer (20.5 $\left.\pm 0.8^{\circ} \mathrm{C}\right)$ and coolest in winter $\left(11.0 \pm 0.7^{\circ} \mathrm{C}\right)$ (Table I). We observed no difference between the water temperatures in the stream and the culture tank during the year (Tab. I).

In crayfishes collected in the creek there were no significant seasonal variations in the levels of glucose in the haemolymph. In the crayfish in the tank, glucose concentration rose in spring and summer, and decreased in other seasons. There was a significant difference between glucose contents of the crayfish in the creek and in the tank (Fig. 1).

The total-protein response profile was the same in animals from the creek and the tank. During the summer, total proteins increased, and then decreased until spring, to levels approximately $50 \%$ lower than in the summer in both places (Fig. 2).

In crayfish collected in the creek and in the tank, there were no significant seasonal variations in the levels of total lipids in the haemolymph (Fig. 3). There was no significant difference in total lipid content between animals from the creek and the tank.

The concentrations of triglycerides in haemolymph (Fig. 4) in animals collected in the creek reached minimum values in summer, and gradually rose in the following seasons, with a significant difference between the concentrations during summer and spring. The crayfishes kept in the tank showed no significant variations in this metabolic parameter. There was no significant difference in triglyceride content between the two populations.

The free glucose in the hepatopancreas of crayfish from the creek and from the tank showed no significant seasonal variations (Tab. II). Glycogen levels increased in animals in the natural environment in the autumn, and decreased in summer. In the experimental culture, glycogen increased significantly in winter, and decreased 6-fold in spring and summer. However, there was no significant difference between the glycogen contents in the two populations (Tab. II). The concentrations of total lipids of the animals collected in the natural environment showed no seasonal variation in the hepatopancreas. However, the animals in the experimental culture showed the highest values of total lipids in the summer, with a decrease of approximately $50 \%$ in the autumn; lipid levels in the hepatopancreas remained low in the subsequent seasons. There was a significant difference between total lipids content in the natural and experimental populations (Table 2). Triglyceride levels in the hepatopancreas of crayfish from the creek and the tank showed no significant seasonal variations (Tab. II).

The free glucose levels in gills of crayfish from the natural environment and experimental culture

Table I. Seasonal variations of water temperature in Garapiá Creek and in the experimental culture tank. The results are expressed as the mean \pm standard error of the mean.

\begin{tabular}{lcc}
\hline Season & Creek Temperature $\left({ }^{\circ} \mathrm{C}\right)$ & Tank \\
\hline Spring & $16.8 \pm 0.7$ & $15.8 \pm 0.8$ \\
Summer & $20.5 \pm 0.8$ & $19.3 \pm 0.9$ \\
Autumn & $14.5 \pm 1.5$ & $14.8 \pm 1.5$ \\
Winter & $11.0 \pm 0.7$ & $11.3 \pm 0.8$ \\
\hline
\end{tabular}




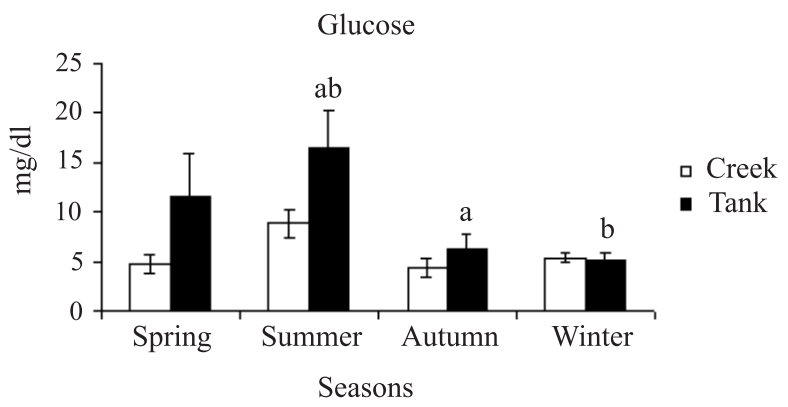

Fig. 1. Seasonal concentration of glucose in the haemolymph of Parastacus brasiliensis collected in the natural environment and the experimental culture. Columns represent the mean and bars the standard error of the mean. The number of animals represented by each point varied between 18 and 21 . Results are expressed in $\mathrm{mg} / \mathrm{dl}$. The same letters represents significant difference between the seasons. \# Significant difference between environments.

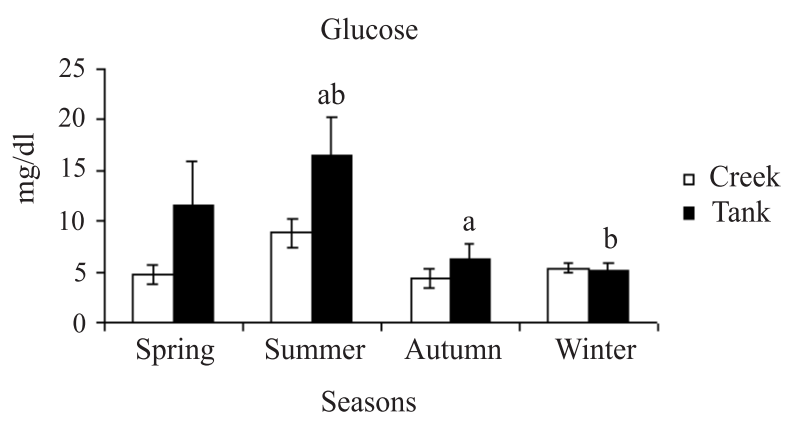

Fig. 2. Seasonal concentration of total proteins in the haemolymph of Parastacus brasiliensis collected in the natural environment and the experimental culture. Columns represent the mean, and bars the standard error of the mean. The number of animals represented by each point varied between 18 and 21. Results are expressed in $\mathrm{mg} / \mathrm{dl}$. The same letter represents significant difference between the seasons.

showed no seasonal variations. There was no significant difference between free glucose content in the two populations (Tab. III). In the naturalenvironment animals, the levels of glycogen in gills increased in winter, and then decreased 12 -fold by summer. In the animals in the experimental culture the glycogen content in the gills increased in winter 21 times-fold, and decreased 29 times approximately in spring, maintained constant in the other seasons. There was no significant difference in glycogen content between the two populations (Tab. III). In animals from the creek, the content of total lipids in the gills showed no seasonal variation. The animals from the experimental culture showed the highest lipid levels in the gills in winter, and an approximately 6fold decrease by summer, which then remained steady until beginning to rise again in autumn. There was a significant difference between total lipids content in animals from the two populations (Tab. III). The triglyceride levels in gills of crayfish from the natural environment and the experimental culture showed no seasonal variations (Tab. III).

The levels of free glucose in muscle tissue showed

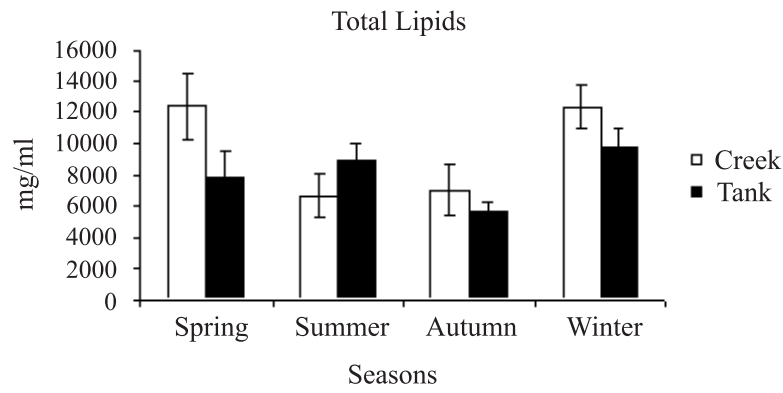

Fig. 3. Seasonal concentration of total lipids in the haemolymph of Parastacus brasiliensis collected in the natural environment and the experimental culture. Columns represent the mean, and bars the standard error of the mean. The number of animals represented by each point varied between 18 and 21. Results are expressed in $\mathrm{mg} / \mathrm{ml}$. The same letter represents significant difference between the seasons.

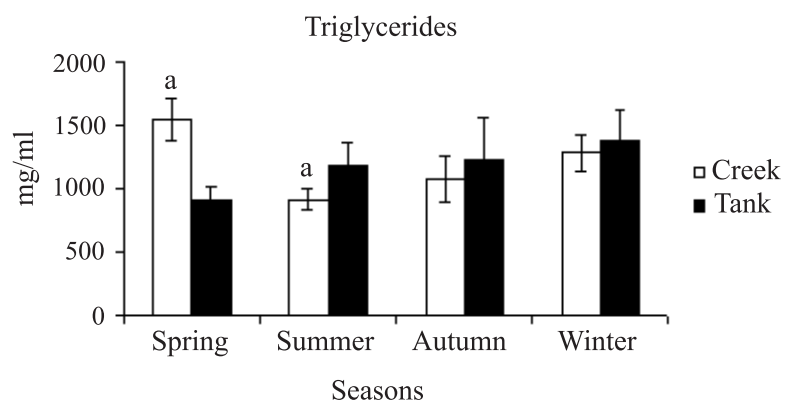

Fig. 4. Seasonal concentration of triglycerides in the haemolymph of Parastacus brasiliensis collected in the natural environment and the experimental culture. Columns represent the mean, and bars the standard error of the mean. The number of animals represented by each point varied between 18 and 21. Results are expressed in $\mathrm{mg} / \mathrm{ml}$. The same letter represents significant difference between the seasons.

seasonal variation only in the crayfish from the creek, where free glucose was highest in spring and lowest in autumn (approximately 3 times less). There was a significant difference in free glucose content between the crayfish from the two sites (Tab. IV). Table IV shows the seasonal variations in the concentrations of glycogen in muscle of $P$. brasiliensis from the creek; polysaccharide peaked in winter and then gradually decreased until autumn. The same response was observed in animals in the culture tank. There was no statistically significant difference in glycogen content between crayfish from the stream and in the tank.

In muscle tissue, the levels of total lipids were low in spring in both groups. In animals from the creek, we observed a peak in autumn; whereas in crayfish from the tank, the peak occurred in winter. There was a significant difference in total lipids content between crayfish of the two populations (Tab. IV). The levels of muscle triglycerides showed seasonal variation only in the animals from the experimental culture: they were highest during winter, and lowest in summer. There was a significant difference in triglyceride content between the populations (Tab. IV). 
Table II. Seasonal concentration of free glucose (FG), glycogen (GLY), total lipids (TL), and triglycerides (TG) in the hepatopancreas of Parastacus brasiliensis collected in the natural environment and in the experimental culture. All results represent the mean \pm standard error of the mean, and are expressed in $\mathrm{mg} / \mathrm{g}$. The same letter represents significant difference between the seasons. \# Significant difference between environments.

\begin{tabular}{|c|c|c|c|c|c|c|c|c|}
\hline \multirow{3}{*}{ Season } & \multicolumn{8}{|c|}{ HEPATOPANCREAS } \\
\hline & \multicolumn{4}{|c|}{ Creek } & \multicolumn{4}{|c|}{ Tank } \\
\hline & FG & GLY & $\mathrm{TL}$ & TG & FG & GLY & $\mathrm{TL}$ & $\mathrm{TG}$ \\
\hline Spring & $0.032 \pm 0.006$ & $0.005 \pm 0.001^{b}$ & $8.252 \pm 1.572$ & $1.637 \pm 0.406$ & $0.041 \pm 0.007$ & $0.002 \pm 0.0003^{\mathrm{a}}$ & $21.99 \pm 5.440^{\mathrm{a}}$ & $3.713 \pm 1.188$ \\
\hline Summer & $0.041 \pm 0.008$ & $0.002 \pm 0.0004^{\mathrm{a}}$ & $11.574 \pm 1.571$ & $0.909 \pm 0.209$ & $0.078 \pm 0.004$ & $0.002 \pm 0.0005^{\mathrm{b}}$ & $37.229 \pm 10.063^{\mathrm{a}}$ & $2.749 \pm 0.852$ \\
\hline Autumn & $0.055 \pm 0.003$ & $0.011 \pm 0.002^{\mathrm{ab}}$ & $4.081 \pm 1.987$ & $3.435 \pm 0.359$ & $0.049 \pm 0.007$ & $0.005 \pm 0.0002^{\mathrm{c}}$ & $26.929 \pm 5.274$ & $2.403 \pm 0.588$ \\
\hline Winter & $0.042 \pm 0.002$ & $0.006 \pm 0.002$ & $12.255 \pm 1.09$ & $2.127 \pm 0.55$ & $0.034 \pm 0.004$ & $0.013 \pm 0.003^{\mathrm{abc}}$ & $22.718 \pm 2.879$ & $2.895 \pm 1.153$ \\
\hline
\end{tabular}

Table III. Seasonal concentration of free glucose (FG), glycogen (GLY), total lipids (TL), and triglycerides (TG) in the gills of Parastacus brasiliensis collected in the natural environment and the experimental culture. All results represent the mean \pm standard error of the mean, and are expressed in $\mathrm{mg} / \mathrm{g}$. The same letter represents significant difference between the seasons. \# Significant difference between environments.

\begin{tabular}{|c|c|c|c|c|c|c|c|c|}
\hline \multirow{3}{*}{ Season } & \multicolumn{8}{|c|}{ GILLS } \\
\hline & \multicolumn{4}{|c|}{ Creek } & \multicolumn{4}{|c|}{ Tank } \\
\hline & $\mathrm{FG}$ & GLY & $\mathrm{TL}$ & $\mathrm{TG}$ & FG & GLY & $\mathrm{TL}$ & $\mathrm{TG}$ \\
\hline Spring & $0.009 \pm 0.002$ & $0.009 \pm 0.002$ & $1.822 \pm 0.889$ & $0.242 \pm 0.116$ & $0.014 \pm 0.001$ & $0.006 \pm 0.002^{\mathrm{a}}$ & $4.438 \pm 1.462^{\mathrm{a}}$ & $0.770 \pm 0.027$ \\
\hline Summer & $0.012 \pm 0.002$ & $0.001 \pm 0.000^{\mathrm{a}}$ & $3.377 \pm 0.035$ & $0.192 \pm 0.029$ & $0.022 \pm 0.002$ & $0.009 \pm 0.003^{\mathrm{b}}$ & $3.812 \pm 1.975^{\mathrm{b}}$ & $0.345 \pm 0.031$ \\
\hline Autumn & $0.014 \pm 0.002$ & $0.006 \pm 0.017$ & $2.852 \pm 0.552$ & $0.165 \pm 0.047$ & $0.021 \pm 0.002$ & $0.008 \pm 0.002^{\mathrm{c}}$ & $13.928 \pm 6.883$ & $0.905 \pm 0.283$ \\
\hline Winter & $0.012 \pm 0.002$ & $0.011 \pm 0.005^{\mathrm{a}}$ & $10.054 \pm 3.873$ & $1.463 \pm 0.624$ & $0.023 \pm 0.002$ & $0.175 \pm 0.004^{\mathrm{abc}}$ & $25.358 \pm 6.614^{\mathrm{ab}}$ & $1.091 \pm 0.509$ \\
\hline
\end{tabular}

Table IV. Seasonal concentration of free glucose (FG), glycogen (GLY), total lipids (TL), and triglycerides (TG) in the abdominal muscle of Parastacus brasiliensis collected in the natural environment and the experimental culture. All results represent the mean \pm standard error of the mean, and are expressed in $\mathrm{mg} / \mathrm{g}$. The same letter represents significant difference between the seasons. \# Significant difference between environments.

\begin{tabular}{|c|c|c|c|c|c|c|c|c|}
\hline \multirow{3}{*}{ Season } & \multicolumn{8}{|c|}{ ABDOMINAL MUSCLE } \\
\hline & \multicolumn{4}{|c|}{ Creek } & \multicolumn{4}{|c|}{ Tank } \\
\hline & FG & GLY & $\mathrm{TL}$ & $\mathrm{TG}$ & FG & GLY & $\mathrm{TL}$ & $\mathrm{TG}$ \\
\hline Spring & $0.028 \pm 0.006^{\mathrm{ab}}$ & $0.022 \pm 0.008^{\mathrm{a}}$ & $0.019 \pm 0.003^{\mathrm{ab}}$ & $0.018 \pm 0.020$ & $0.035 \pm 0.009$ & $0.009 \pm 0.003$ & $0.469 \pm 0.016^{\mathrm{a}}$ & $0.028 \pm 0.006^{\mathrm{a}}$ \\
\hline Summer & $0.010 \pm 0.003^{\mathrm{a}}$ & $0.002 \pm 0.0007^{\mathrm{ab}}$ & $0.053 \pm 0.009^{\mathrm{cd}}$ & $0.004 \pm 0.0002$ & $0.020 \pm 0.003$ & $0.006 \pm 0.003^{\mathrm{a}}$ & $0.293 \pm 0.046^{\mathrm{b}}$ & $0.005 \pm 0.004$ \\
\hline Autumn & $0.009 \pm 0.002^{\mathrm{b}}$ & $0.001 \pm 0.0005^{\mathrm{c}}$ & $0.613 \pm 0.117^{\mathrm{ac}}$ & $0.021 \pm 0.006$ & $0.018 \pm 0.002$ & $0.003 \pm 0.001^{\mathrm{b}}$ & $0.412 \pm 0.049^{c}$ & $0.029 \pm 0.012^{\mathrm{ab}}$ \\
\hline Winter & $0.022 \pm 0.004$ & $0.033 \pm 0.008^{\mathrm{bc}}$ & $0.556 \pm 0.107^{\mathrm{bd}}$ & $0.028 \pm 0.007$ & $0.031 \pm 0.004$ & $0.034 \pm 0.014^{\mathrm{ab}}$ & $1.028 \pm 0.189^{\mathrm{abc}}$ & $0.046 \pm 0.009^{\mathrm{b}}$ \\
\hline
\end{tabular}

\section{DISCUSSION}

The levels of proteins, carbohydrates, and lipids are an expression of an animal's adaptative characteristics and its strategies for adaptation in a determinate habitat. Many biotic factors (e.g., maturation, reproduction, and food availability) and abiotic factors (e.g., photoperiod, temperature, $\mathrm{pH}$, and oxygen in water) can strongly affect the biochemistry and physiology of decapod crustaceans (Company \& SARDÀ, 1998; Rosa \& Nunes, 2003a, 2003b; VINAGRE et al., 2006).

The concentration of glucose in the haemolymph of $P$. brasiliensis collected in the natural environment (creek) ranged from $4.3 \pm 1.0$ to $8.8 \pm 1.3 \mathrm{mg} / \mathrm{dl}$. These values of glucose are similar to those obtained in the crab $C$. granulatus maintained in laboratory conditions on a high-protein diet (KUCHARSKI \& DA SILVA, 1991a; Oliveira et al., 2004), and contrast with the results observed in crabs and lobster maintained on a carbohydrate-rich diet, which showed increased levels of circulating glucose (Vinagre \& Da Silva, 1992; RADFORD et al., 2005). We can therefore infer that the natural diet of $P$. brasiliensis is high in protein and low in carbohydrate. Other species of parastacids are often polytrophic or omnivorous and opportunist feeders and plant detritus may be the main item in their natural diet (GOODARD, 1988; HoOGer, 1988; Hollows et al., 2002).

Crayfish maintained in the tank and receiving food supplement showed increased glucose levels in spring and summer, with a wider seasonal variation. This increase in glucose levels may be due to a decrease of the glycogen in the hepatopancreas and muscle, associated with regular food intake. Haemolymphatic glucose is the result of the influx of intestinal glucose, from the gluconeogenic pathway and the utilization of this hexose in different processes (Chang \& O'Connor, 1983; Oliveira \& DA SILVA, 1997).

The seasonal variation observed in $P$. brasiliensis of circulating glucose and glycogen levels in the hepatopancreas and muscle, in animals from both the creek and the tank, and of gills only in crayfish from the creek, followed the same pattern described by OLIVEIRA et al. (2003) for Aegla ligulata Bond-Buckup \& Buckup, 1994, a freshwater anomuran also found in this region. In winter, the exploratory activity of $P$. brasiliensis is reduced, and this is reflected in the difficulty of collecting the crayfish at this season. Other crustaceans have a shorter activity period and decreased metabolism, as well as higher glycogen levels in the hepatopancreas during winter (Kucharski \& Da Silva, 1991b; Oliveira et al., 
2003; VinAGRE et al., 2006). This may account for the higher glycogen levels in all the tissues examined (hepatopancreas, gills, and muscle) during winter.

These findings suggest that glycogen reserves may be used during spring and summer for exploratory activity and reproduction (gametogenesis and vitellogenesis). The yolk protein, vitellin, is a glycolipoprotein in many crustacean species (RILEY \& TSUKIMURA, 1988; TSENG et al., 2001). Reinforcing this hypothesis, we observed a decrease in the levels of total proteins in the haemolymph in spring. In the local wild population of this species, reproduction begins in spring and continues until summer, and the number of ovigerous females peaks in November. Fontoura \& BUCKUP (1989b) observed two phases in the reproductive period in $P$. brasiliensis. During the first phase, the eggs are laid and attached to the pleopods of the female. The second phase occurs after hatching, and the juveniles remain on the pleopods (maturation of juvenile phase).

Comparing glycogen and glucose in all tissues examined, for the animals both in the stream and the tank, we observed levels up to 10 times lower than those found in other species of crustaceans (KUCHARSKI \& DA SILVA, 1991 a, 1991b; Oliveira et al., 2001, 2003; Ferreira et al., 2005). However, the levels of total lipids and triglycerides remained high similar to other crayfishes, which may suggest that in these animals, lipids are a very important energy reserve. In all tissues (hepatopancreas, gills and muscle) the levels of total lipids and triglycerides were higher in those animals which were fed regularly (culture tank), indicating that these metabolites are preferentially stored.

In P. brasiliensis collected both in the creek and the tank, triglyceride levels in the haemolymph decreased significantly in summer. This reduction in circulating triglycerides may be related to the reproductive period, when lipid reserves may be used for reproduction (gametogenesis and vitellogenesis). This suggestion is reinforced by the sharp decrease in lipid content in the hepatopancreas and muscle during spring and summer in crayfish collected in both places. Crustacean vitellin is a glycoprotein that has an LDL and an HDL fraction, and these fractions contain different proportions of proteins, carotenoids, phospholipids, and triacylglycerol (Komatsu, 1992; Petersen \& ANGer, 1997).

Parastacus brasiliensis, like other crayfishes, produces large, lecithotrophic eggs (FARMER, 1974). The egg size is related to maternal investment, mainly the lipid metabolism (ROSA \& NUNES 2003a, 2003b). Lipids are the main source of energy throughout embryonic development, and the amount of lipids is generally correlated with the size of eggs and the time interval between spawning and hatching (Petersen \& Anger, 1997; Rainuzzo et al., 1997). In P. brasiliensis, development is direct and the juveniles remain on the pleopods of the female until 9 days after eclosion, and then separate gradually over about 4 days. In another creek in Rio Grande do Sul, females of P. brasiliensis hatched their eggs after $41 \pm 5$ days, and the juveniles remained on the pleopods for $9 \pm 3$ days (FonTOURA \& Buckup, 1989b). In this study, the water temperature varied between 14 and $19^{\circ} \mathrm{C}$.
In conclusion, the results suggest that, in $P$. brasiliensis, the environmental conditions (e.g., water temperature and food availability) and the reproductive period appear to be the main processes influencing the seasonal patterns in the crayfish' biochemical composition.

Acknowledgements. This work was supported by grants from Fundação de Amparo à Pesquisa do Rio Grande do Sul (FAPERGS) $n^{\circ}$ 01509093. The Pontifícia Universidade Católica do Rio Grande do Sul supported this work. The experiments were performed according with the current Brazilian laws.

\section{REFERENCES}

Almeida, A. O. \& Buckup, L. 1999. Caracteres sexuais primários e secundários do lagostim Parastacus defossus Faxon, 1898 (Crustacea, Parastacidae). Nauplius 7:113-126.

Buckup, L. \& Rossi, A. 1980. O gênero Parastacus no Brasil (Crustacea, Decapoda, Parastacidae). Revista Brasileira de Biologia 40:663-681.

Buckup, L. 1999. Família Parastacidae. In: Buckup L. \& BondBuckup G. eds. Os Crustáceos do Rio Grande do Sul. Editora UFRGS, Porto Alegre Brasil. p.319-327.

CARr, R. S. \& NefF, J. M. 1984. Quantitative semi-automated enzymatic assay for tissue glycogen. Comparative Biochemistry and Physiology B 77:447-449.

Chang, E. \& O'Connor, J. D. 1983. Metabolism and transport of carbohydrates and lipids. In: Mantell. L. H. ed. The Biology of Crustacea: Internal Anatomy and Physiological Regulation. Academic Press, New York p.263-287.

Company, J. B. \& SARDÀ, F. 1998. Metabolic rates and energy content of deep-sea decapod crustaceans in the Western Mediterranean Sea. Deep-Sea Research Part I 45:1861-1880.

FARMER, A. S. D. 1974. Reproduction in Nephrops norvegicus (Decapoda: Nephropidae). Journal of Zoology 174:161-183.

Ferreira, B. D. P.; Hack, C. S.; Ollveira, G. T. \& Bond-Buckup, G. 2005. Perfil metabólico de Aegla platensis Schmitt, 1942 (Crustacea, Anomura) submetida a dietas ricas em carboidratos ou proteínas. Revista Brasileira de Zoologia 22:161-168.

Folch, J.; Lees, M. \& Sloane-Stanley, G. H. 1957. A simple method for isolation and purification of total lipids from animal tissues. Journal of Biological Chemistry. 226:497-509.

Fontoura, N. F. \& Buckup, L. 1989a. O crescimento de Parastacus brasiliensis (Von Martens, 1869) (Crustacea, Decapoda, Parastacidae). Revista Brasileira de Biologia 49:897-909. 1989b. Dinâmica populacional e reprodução em Parastacus brasiliensis (Von Martens, 1869) (Crustacea, Decapoda, Parastacidae). Revista Brasileira de Biologia 49:911-921.

Frings, C.S. \& DunN, R.T. 1970. A Colorimetric Method for Determination of Total Serum Lipids Based on the Sulfophosphovanillin Reaction. American Journal of Clinical Pathology 53:89-91.

FriEs, B. G. 1980. Observações sobre o lagostim de água doce Parastacus brasiliensis (von Martens, 1869) em condições de cultivo experimental em laboratório (Crustacea, Decapoda, Parastacidae). Revista Brasileira de Biologia 44:409-416.

Garcia, F.; González-Baró, M. \& Pollero, R. 2002. Transfer of lipids between hemolymph and hepatopancreas in the shrimp Macrobrachium borellii. Lipids 37: 581-585.

Geary, N.; Langhans, W. \& Scharrer, E. 1981. Metabolic concomitants of glucagon-induced suppression of feeding in the rat. American Journal of Physiology 241:R330-R335.

Gilles, R. 1982. Osmoregulatory processes in mollusks and crustacean from media with fluctuating salinity regime. Biological Fisiology Animal 6:1-36.

Goodard, J. S. 1988. Food and feeding. In: Holdich D. M. \& LOWERY R. S. ed. Freshwater crayfish: biology, management and exploration. Timber Press, Portland. p.145-166.

Herreid, C. F. \& Full, R. J. 1988. Energetics and locomotion In: MacMahon B. ed. Biology of Land Crabs, Cambridge University Press, Cambridge p.337-377.

Hochachкa, P. W.; Somero, G. N.; Schneider, D. E. \& Freed, J. M. 1970. The organization and control of metabolism in the 
crustacean gill. Comparative Biochemistry and Physiology A 33:529-548.

Hogger, J. B. 1988. Ecology, population biology and behavior. In: Holdich, D. M. \& Lowery, R. S. eds. Freshwater Crayfish: biology, management and exploitation. Timber Press, Portland. p.114-144.

Hollows, J. W.; Townsend, C. R. \& Collier, K. J. 2002. Diet of the crayfish Paranephrops zealandicus in bush and pasture streams: insights from stable isotopes and stomach analysis. New Zealand Journal Marine Fresh. 36:129-142.

Johnston, M. A. \& Davies, P. S. 1972. Carbohydrates of the hepatopancreas and blood tissues of Carcinus. Comparative Biochemistry and Physiology B 41:433-443.

Komatsu, M. \& ANDO, S. 1992. Isolation of crustacean egg yolk lipoproteins by differential density gradient ultracentrifugation. Comparative Endocrinology 20:572-578.

Kucharski, L. C. R. \& Da Silva, R. S. M. 1991a. Effect of diet composition on the carbohydrate and lipid metabolism in an estuarine crab, Chasmagnathus granulata (Dana, 1851). Comparative Biochemistry and Physiology A 99:215-218. 1991b. Seasonal variation on the energy metabolism in an estuarine crab, Chasmagnathus granulata (Dana, 1851). Comparative Biochemistry and Physiology A 100:599-602.

Lowry, O.H.; Rosebrough, N.J.; Farr, A.L. \& Randall, R.J. 1951. Protein measurements with the folin phenol reagent. Journal of Biological Chemistry 183:265-275.

Muriana, F. J. G.; Ruiz-Gutierrez, V.; Gallardo-Guerrero, M. L. \& Minguez-Mosquera, M. L. 1993. A study of the lipids and carotenoprotein in the prawn Penaeus japonicus. Journal of Biochemistry 114:223-229.

O’Connor, J. D. \& Gilbert, L. I. 1968. Aspects of lipid metabolism in Crustaceans. American Zoology. 8:529-539.

Oliveira, G. T. \& DA Silva, R. S. M. 1997. Glyconeogeneses in hepatopancreas from Chasmagnathus granulata crabs maintained on high- protein or carbohydrate-rich diets. Comparative Biochemistry and Physiology A 118:1429-1435.

Oliveira, G. T.; Rossi, I. C. C. \& Da Silva, R. S. M. 2001. Carbohydrate metabolism during anoxia and pos-anoxia recovery in Chasmagnathus granulata crabs maintained on high-protein or carbohydrate-rich diets. Marine Biology 139:335-342.

Oliveira, G. T.; Fernandes, F. A.; Bond-Buckup, G.; Bueno, A. A. \& Da SiLva, R. S. M. 2003. Circadian and seasonal variations in the metabolism of carbohydrates in Aegla ligulata (Crustacea: Anomura: Aeglidae). Memoirs of Museum Victoria 60:59-62.

Oliveira, G. T.; Eichler, P.; Rossi, I. C. C. \& Da Silva, R. S. M. 2004. Hepatopancreas gluconeogenesis during anoxia and post-anoxia recovery in Chasmagnathus granulata crabs maintained on high-protein or carbohydrate-rich diets. Journal Experimental Zoology A 301:240-248.

Petersen, S. \& Anger, K. 1997. Chemical and physiological changes during the embryonic development of the spider crab Hyas araneus L (Decapoda: Majidae). Comparative Biochemistry and Physiology A 117:299-306.

Rainuzzo, J. R.; Reitan, K. I. \& Olsen, Y. 1997. The significance of lipids at early stages of marine fish: a review. Aquaculture
155:103-116.

Radford, C. A.; Marsden, I. D.; Davison, W. \& TAYlor, H. H. 2005. Haemolymph glucose concentrations of juvenile rock lobsters, Jasus edwardsii, feeding on different carbohydrate meals. Comparative Biochemistry and Physiology A 140:241-249.

Riley, L. G. \& Tsukimura, B. 1988. Yolk protein synthesis in the riceland tadpole shrimp, Triops longicaudatus, measured by in vitro incorporation of ${ }^{3} \mathrm{H}$-leucine. Journal Experimental of Zoology 281:238-247.

Rosa, R. \& Nunes, M. L. 2003a. Biochemical composition of deep-sea decapod crustaceans with two different benthic life strategies off the Portuguese south coast. Deep-Sea Research Part I 150:119-130.

. 2003b. Changes in organ indices and lipid dynamics during the reproductive cycle of Aristeus antennatus, Parapenaeus longirostris and Nephrops norvegicus (Crustacea: Decapoda) females from the south Portuguese coast. Crustaceana, 75: 1095-1105.

Schirf, V. R.; Turner, L. S.; Hanapel, C.; De La Cruz, P. \& Dehn, P. F. 1987. Nutritional status and energy metabolism of crayfish (Procambarus clarkii, Girardi) muscle and hepatopancreas. Comparative Biochemistry and Physiology A 88:383-386. Schein, V.; Waché, Y.; Etges, R.; Kucharski, L. C.; Wormhoudt, A. V. \& Da Silva, R. S. M. 2004. Effect of hyperosmotic shock on phosphoenolpyruvate carboxykinase gene expression and gluconeogenic activity in the crab muscle. FEBS Letters 561:202-206.

Silva-Castiglioni, D.; Dutra, B. K.; Oliveira, G. T. \& Bond- Buckup, G. 2007a. Seasonal variations of the intermediate metabolism of Parastacus varicosus Faxon, 1898 (Crustacea, Decapoda, Parastacidae) Comparative Biochemistry and Physiology A 148:204-213.

Tseng, D. Y.; Chen, Y. N.; Kou, G. H.; Lo, C. F. \& Kuo, C. M. 2001. Hepatopancreas is the extraovarian site of vitellogenin synthesis in black tiger prawn Penaeus monodon. Comparative Biochemistry and Physiology A 129:909-917.

VAN HANDEL, E. 1965. Estimation of glycogen in small amount of tissue. Analitical Biochemistry 11:256-265.

VINAGRE, A. S. \& DA SILVA, R. S. M. 1992. Effects of starvation on the carbohydrate and lipid metabolism in crabs previously maintained on a high-protein or carbohydrate-rich diet. Comparative Biochemistry and Physiology A 102:579-583. 2002. Effects of fasting and refeeding on metabolic processes in crabs Chasmagnathus granulata (Dana, 1851). Canadian Journal of Zoology 80:1413-1421.

Vinagre, A. S.; Amaral, A. P. N.; Ribarcki, F. P.; Silveira, E. F. \& Périco, E. 2006. Seasonal variation of energy metabolism in ghost crab Ocypode quadrata at Siriú Beach (Brazil). Comparative Biochemistry and Physiology A 146(4):514-519.

Yehezkel, G.; Сhayoth, R.; Abdu, U.; Khalaila, I. \& Sagi, A. 2000 High-density lipoprotein associated with secondary vitellogenesis in the hemolymph of the crayfish Cherax quadricarinatus. Comparative Biochemistry and Physiology B 27:411-421.

Recebido em julho de 2007. Aceito em janeiro de 2008. ISSN 0073-4721

Artigo disponível em: www.scielo.br/isz

Iheringia, Sér. Zool., Porto Alegre, 98(3):355-361, 30 de setembro de 2008 